\author{
Izabela Ślęzak \\ Jakub Niedbalski \\ Uniwersytet Łódzki
}

\title{
Główne funkcje programu NVivo a procedury metodologii teorii ugruntowanej, czyli jak realizować badanie oparte na MTU, korzystając z oprogramowania CAQDA? ${ }^{1}$
}

\begin{abstract}
Streszczenie. Celem artykułu jest przybliżenie czytelnikowi możliwości, jakie niesie ze sobą korzystanie z oprogramowania komputerowego wspomagającego analizę danych jakościowych w realizacji projektów badawczych opartych na metodach jakościowych. Przedmiotem analizy jest program NVivo i jego funkcje. W artykule przedstawiamy sposób, w jaki poszczególne opcje tego programu powinny być wykorzystane, aby stanowiły skuteczny środek do prowadzenia badań zgodnie z procedurami metodologii teorii ugruntowanej.

Słowa kluczowe: oprogramowanie komputerowe wspomagające analizę danych jakościowych (CAQDAS), NVivo, metodologia teorii ugruntowanej (MTU).
\end{abstract}

\section{Wstęp}

Technologia odgrywa coraz większą rolę we współczesnym świecie. Jednym z jej oblicz jest stosowanie wszechobecnych komputerów oraz programów, zarówno tych uniwersalnych, jak i specjalistycznych, skierowanych do wąskiego grona odbiorców, jakimi są naukowcy oraz badacze. Oprogramowanie komputerowe jest już od wielu lat wykorzystywane w naukach społecznych i humanistycznych. Wydaje się jednak, że od niedawna zyskało także uznanie badaczy stosujących jakościowe metody analizy danych.

Wśród wielu programów służących wspomaganiu analizy danych jakościowych wybraliśmy NVivo, kierując się naszą wiedzą, a także wieloletnim doświadczeniem w zakresie oprogramowania CAQDA.

W literaturze przedmiotu podkreśla się, że NVivo to narzędzie wspomagające projekty badawcze z zakresu analizy dyskursu, metodologii teorii ugruntowanej, analizy konwersacyjnej, etnografii, badań opartych na fenomenologii,

${ }^{1}$ Tekst stanowi uaktualnioną i wzbogaconą o nowe treści wersję artykułu Niedbalskiego i Ślęzak (2012). 
a także innych, w tym mieszanych metod badawczych (Schönfelder 2011). Niemniej jako badacze stosujący MTU w artykule będziemy patrzeć na opisywany program z perspektywy tej właśnie metody badawczej. Z tego względu pragniemy przedstawić najważniejsze funkcje, jakie udostępnia program NVivo, ze wskazaniem ich przydatności w procesie analizy jakościowej zgodnej z metodologią teorii ugruntowanej.

\section{Metodologia teorii ugruntowanej - podstawowe założenia i procedury}

Wybór metodologii zawsze wiąże się z określonymi założeniami ontologicznymi i epistemologicznymi, które stanowią ramę prowadzonych badań. Jeśli badacz stawia sobie za cel poznanie perspektywy badanych aktorów społecznych i uchwycenie procesualnego wymiaru badanych zjawisk, szczególnie przydatna wydaje się metodologia teorii ugruntowanej (Glaser 1998: 11; zob. Ślęzak 2009: 40-41).

Zgodnie z jej założeniami teoria wyłania się $w$ trakcie systematycznie prowadzonych badań terenowych w wyniku analizy danych empirycznych, bezpośrednio odnoszących się do obserwowanego fragmentu rzeczywistości społecznej (Glaser, Strauss 1967: 1; Strauss, Corbin 1990: 23; Glaser 1998: 3; Konecki 2000: 26). Ma ona charakter teorii średniego zasięgu, której pojęcia wywodzą się z obserwacji i opisu ściśle wyodrębnionego do badań obszaru empirycznego (middle range theory; Merton 2002: 61-93). Generowanie teorii jest procesem, w którym etap zbierania danych nie jest wyraźnie oddzielany od etapu budowania hipotez. Gromadzenie danych empirycznych odbywa się w przypadku stosowania MTU nie stadialnie, fazowo, lecz naprzemiennie z prowadzoną równolegle analizą i interpretacją (Niedbalski, Ślęzak 2012: 131). Oba etapy przeplatają się, a ciągłe powracanie badacza do zebranego materiału gwarantuje, że budowana przez niego teoria rzeczywiście wyłania się z danych empirycznych (Strauss, Corbin 1990: 59; Konecki 2000: 27; Urbaniak-Zając, Piekarski 2001: 24).

Teoria powstaje więc $w$ sposób indukcyjny, na podstawie analizy zbieranych danych. Dopiero na podstawie „wyindukowanych" w ten sposób kategorii prowadzona jest analiza dedukcyjna, wskazująca kolejne grupy przypadków do analiz porównawczych, w wyniku których można osiągnąć bardziej abstrakcyjny poziom teoretycznego powiązania kategorii (Ślęzak 2009: 42). Mamy tu do czynienia z procedurą abdukcji, czyli przechodzenia od indukcji do dedukcji (Strauss, Corbin 1990: 111; Konecki 2000: 45-46; Urbaniak-Zając, Piekarski 2001: 29). Teoria nie jest zatem swobodną twórczością literacką, a żmudną, poddawaną kontroli i „obiektywną" metodologią badawczą (Glaser 1998; Hammersley, Atkinson 2000: 196; Konecki 2000: 32). Jednym z założeń leżących w podstaw 
jej stosowania jest maksymalne ograniczenie prekonceptualizacji badawczej w celu zachowania otwartości i podtrzymania szans na odkrycie zjawisk, których na początku badań nie poszukiwaliśmy i których nie byliśmy świadomi (Konecki 2000: 27). Działaniom tym towarzyszą również inne procedury metodologicznej poprawności. W przypadku MTU należą do nich m.in. teoretyczne pobieranie próbek (theoretical sampling), procedura ciągłego porównywania (constant comparative metod), kodowania, pisania not. Pobieranie próbek ma charakter procesualny i odbywa się do chwili osiągnięcia teoretycznego nasycenia (theoretical saturation), a więc takiego momentu, kiedy nie pojawiają się już żadne nowe dane, a kolejne przypadki są podobne do wcześniejszych i można je zanalizować za pomocą już istniejących kategorii (Glaser 1978: 142).

Warto zaznaczyć, że metodologia teorii ugruntowanej nie jest propozycją jednolitą, niezróżnicowaną wewnętrznie. Z uwagi na to, że przez dziesięciolecia była ona poddawana krytycznej refleksji przez jej twórców, dziś zaś jest stosowana przez kolejne pokolenia badaczy, którzy nierzadko wprowadzają pewne modyfikacje do jej założeń i stosowanych procedur analitycznych, można mówić raczej o metodologiach teorii ugruntowanej (por. Glaser, Strauss 1967; Piotrowski 1985; Bokszański 1986; Ziółkowski 1981; Strauss, Corbin 1990: 24-25; Charmaz 1994; Konecki 2000: 32-47; Gorzko 2008). Nie rozważając w sposób bardziej szczegółowy różnic pomiędzy tymi podejściami, chcielibyśmy jednak podkreślić, że w pracy wykorzystywane jest podejście reprezentowane przez A. Straussa, czerpiące z tradycji symbolicznego interakcjonizmu, co tym samym stanowi spójną całość z przyjmowanymi przeze mnie złożeniami ontologicznymi i epistemologicznymi (Ślęzak 2009: 46).

\section{Krótki opis programu}

Historia oprogramowania NVivo sięga początku lat 80. XX w. Program został opracowany przez Toma Richardsa do wspierania badań społecznych przez Lyn Richards i stał się jednym z pierwszych programów do badań jakościowych. Wersjami programu poprzedzającymi pojawienie się NVivo był NUD*IST (Non-Numerical Unstructured Data Indexing Searching and Theorizing), a następnie oprogramowanie noszące nazwę QSR - od wersji N4 do N6 (Niedbalski 2014). Od tego czasu program przeszedł liczne modyfikacje, a kolejne jego wersje były wzbogacane o coraz nowsze funkcje, lepiej dopasowane do potrzeb badaczy jakościowych. Dynamika zmian sprawia, że co około 2-3 lata ma swoją premierę nowa wersja programu. Obecnie (stan na początek 2014 r.) jest to wersja $10^{2}$.

\footnotetext{
${ }^{2}$ Prezentowane w artykule rozwiązania bazują na wersji 9 programu NVivo.
} 
Program NVivo, pomimo wielu dostępnych w nim opcji, jest dość intuicyjny. Jego wygląd oraz ułożenie poszczególnych funkcji pozwalają nawet niedoświadczonemu użytkownikowi na dość szybkie oswojenie się z nim. W górnej części okna znajduje się rozwijane menu oraz paski narzędzi. Nieco poniżej zamieszczono pasek przeszukiwarki, dzięki któremu użytkownik może wyszukiwać dane ze wszystkich dostępnych źródeł i materiałów znajdujących się w bazie danych. Drugi obszar to menu nawigacji zajmujące lewą część okna interfejsu. Zdecydowanie największą przestrzeń interfejsu zajmuje okno robocze, gdzie wyświetlane są elementy projektu wybrane przez użytkownika.

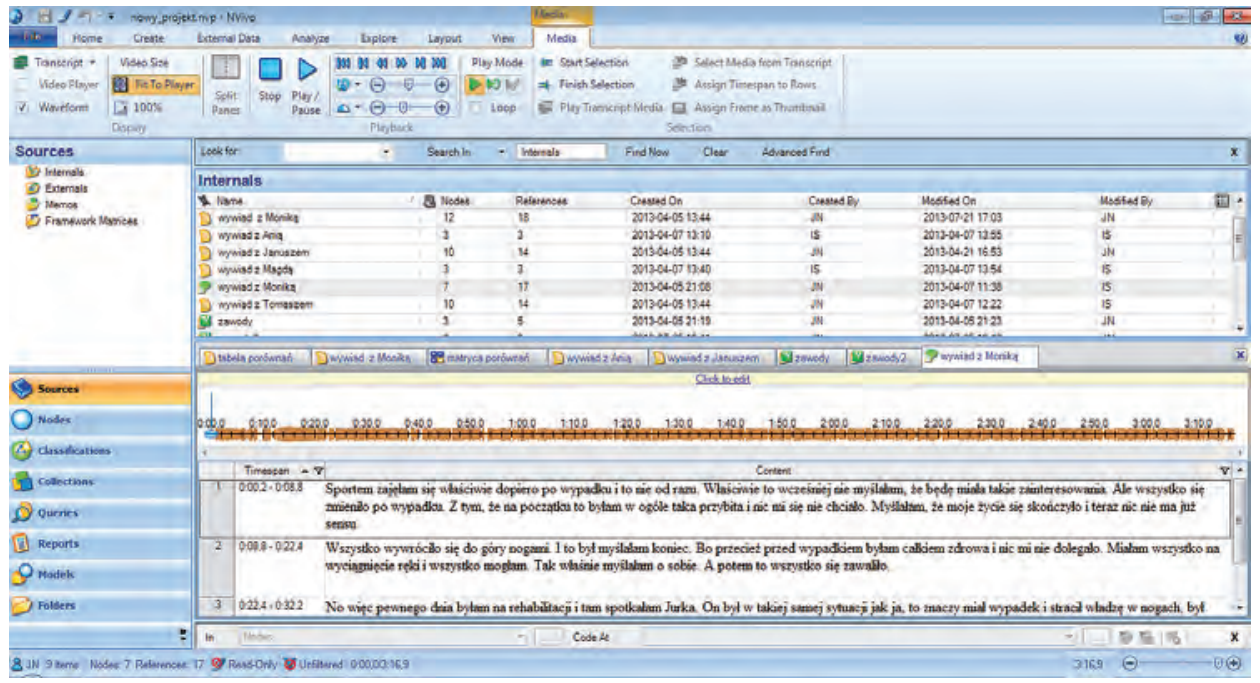

Ilustr. 1. Główne okno programu NVivo

Źródło: opracowanie własne

Pracę w programie rozpoczynamy od utworzenia projektu stanowiącego de facto bazę danych, którą badacz będzie stopniowo zapełniał kolejnymi materiałami. NVivo daje w tym zakresie spore możliwości, bowiem pozwala na zaimportowanie zarówno plików tekstowych, jak i zdjęć, materiałów audio i wideo. Ważne jest przy tym, że oba programy obsługują nie tylko różne rodzaje danych, lecz także wiele ich formatów, co sprawia, że ich zakres zastosowania jest niezwykle szeroki (Niedbalski 2014).

Warto jeszcze zwrócić uwagę na fakt, iż program posiada swoisty system nazewnictwa. Uwagę zwraca przede wszystkim zmiana terminów - „kody” w NVivo funkcjonują pod nazwą „węzły” (Nodes). Dla początkujących użytkowników ta odmienność idiosynkratyczna języka może być nieco problematyczna, ale stosunkowo szybko można się do niej przyzwyczaić (Niedbalski 2014). 


\section{Funkcje NVivo a realizacja projektu opartego na MTU}

Wiedząc jak należy rozpocząć pracę z programem NVivo, możemy przystąpić do czynności stricte analitycznych, związanych z procesem generowania teorii zgodnie z MTU. Będzie nas zatem przede wszystkim interesować możliwość wykorzystania wybranych funkcji dostępnych w programie w taki sposób, aby badacz mógł stosować określone procedury badawcze metodologii teorii ugruntowanej.

Podstawowe elementy teorii to kategorie i ich własności (najbardziej konkretne, dające się skonceptualizować cechy danej kategorii, na tyle specyficzne, by były przydatne $w$ dalszej analizie) oraz hipotezy (powiązania między kategoriami, które badacz odkrywa w trakcie prowadzenia analiz). Kategorie i ich własności generowane są podczas procedury kodowania (coding).

Kluczową rolę odgrywa w tym kontekście proces kodowania, a więc przypisywania partiom materiału określonych etykiet odzwierciedlających ich sens i znaczenie nadawane im przez aktorów społecznych i odwzorowane przez badacza (Niedbalski, Ślęzak 2012: 131). W metodologii teorii ugruntowanej wyróżnia się dwa podstawowe typy kodowania: rzeczowe i teoretyczne. Kodowanie rzeczowe oznacza skonceptualizowanie danego obszaru badań poprzez stosowanie (często naprzemiennie) trzech rodzajów kodowania: otwartego (open), zogniskowanego (axial) oraz selektywnego (selective) (Strauss, Corbin 1990: 57-116).

Kodowanie otwarte stanowi podstawę dla pozostałych typów kodowań. Polega ono na przypisaniu etykiet (na wszystkie możliwe sposoby) zebranemu materiałowi empirycznemu, zidentyfikowaniu kategorii, ich własności i w konsekwencji przejściu od danych na poziom konceptualny. Polega na przypisaniu do jednego lub większej liczby akapitów określonego słowa bądź zwrotu. Kod ma zatem charakter pojęcia, które informacjom opisowym przypisuje znaczenie (Gorzko 2008: 93). Strauss i Corbin (1990: 74) definiują je jako „proces analityczny, w którym pojęcia są określone i opracowane pod względem ich właściwości i wymiarów". Cel ten jest realizowany poprzez poszukiwanie znaczeń ukrytych w danych, dokonywanie ich porównań, a także rozwijanie i tworzenie bardziej ogólnych kategorii dla podobnych zjawisk (Strauss, Corbin 1990).

Wykonywanie tego rodzaju kodowania w programie NVivo odbywa się poprzez zaznaczanie fragment po fragmencie tekstu, któremu następnie nadaje się określone etykiety (Niedbalski 2014). Co istotne, wygenerowane kody mogą podlegać modyfikacjom w zależności od kolejnych ustaleń badacza, a także jego ewoluujących pomysłów. Oznacza to, że kod raz nadany może zmienić swoją nazwę, zostać połączony z innym kodem bądź też, w miarę jak będzie postępował proces teoretyzowania, może być zastąpiony innym kodem. W NVivo możemy istniejące kody kopiować (Copy), wycinać (Cut), usuwać (Delete), zmieniać ich nazwę (Rename) czy włączać jeden kod w drugi (Merge). 


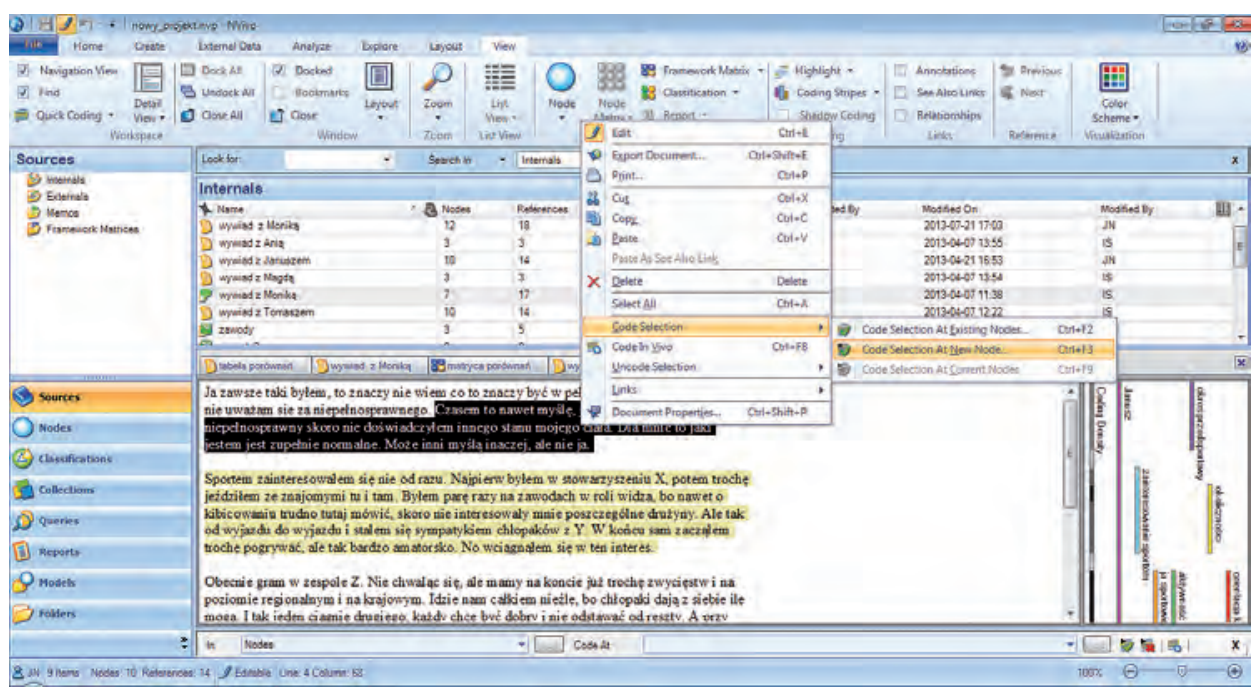

Ilustr. 2. Kodowanie otwarte w programie NVivo

Źródło: opracowanie własne

Kodowanie nie może się ograniczać do wykrycia kategorii i ich nazwania. Elementami, z których składa się teoria, są m.in. kategorie i ich własności. Te pierwsze przedstawia się jako „pojęciowe elementy teorii”, a więc podstawowe składniki, z których są one budowane. Kategorie stanowią pojęciowe odpowiedniki zjawisk (Gorzko 2008: 79) i, zgodnie ze stwierdzeniem Glasera i Straussa, „opierają się na samych sobie" (1967: 36). Jak podają wspomniani autorzy, jest to podstawą do ich odróżnienia od własności. Te ostatnie mają zaś sens jedynie wtedy, gdy są konceptualnymi aspektami albo elementami kategorii. Pomiędzy kategoriami a własnościami zachodzi więc różnica ogólności (Gorzko 2008: 79). Jak twierdzi Marek Gorzko (2008: 80), twórcy teorii ugruntowanej zakładali bowiem, że ogólne kategorie stanowią trzon teorii i są konstruowane z elementów niższego rzędu. Co więcej, kategorie muszą być rozwinięte w terminach swoich własności. Im więcej tych pojęciowych komponentów (składników, własności) zostanie objętych analizą, tym lepiej są opisane kategorie i tym „gęstsza” jest budowana z ich użyciem teoria (Gorzko 2008: 81). Dlatego kolejnym krokiem w analizie opartej na MTU jest kodowanie zogniskowane, w trakcie którego określane są powiązania między kategoriami i subkategoriami. Pomocny w ich odnalezieniu może być paradygmat kodowania (coding paradigm). Składają się na niego warunki przyczynowe (causal conditions) wystąpienia analizowanego zjawiska (phenomenon), kontekst (context), w jakim zachodzi, warunki interweniujące w jego przebieg (intervening conditions), a także działania, strategie interakcyjne, które mu towarzyszą (action/ interaction strategies) oraz konsekwencje (consequences) występowania tych 
czynników (Strauss, Corbin 1990: 99; Konecki 2000: 48-55). Dodatkowym narzędziem analitycznym jest matryca warunków (conditional matrix) ułatwiająca kodowanie i opis warunków przyczynowych, interweniujących oraz kontekstu występowania danego zjawiska (Strauss, Corbin 1990: 158-173; Konecki 2000: 50-51).

W praktyce program NVivo umożliwia utworzenie uporządkowanej struktury kodów, a więc drzewa kategorii. Co więcej, w samym drzewie kategorii można, w miarę jak będzie postępował proces analityczny, dokonywać określonych zmian i modyfikacji. Mogą one polegać na przykład na zmianie położenia względem siebie kategorii pozostających na tym samym poziomie w hierarchii.

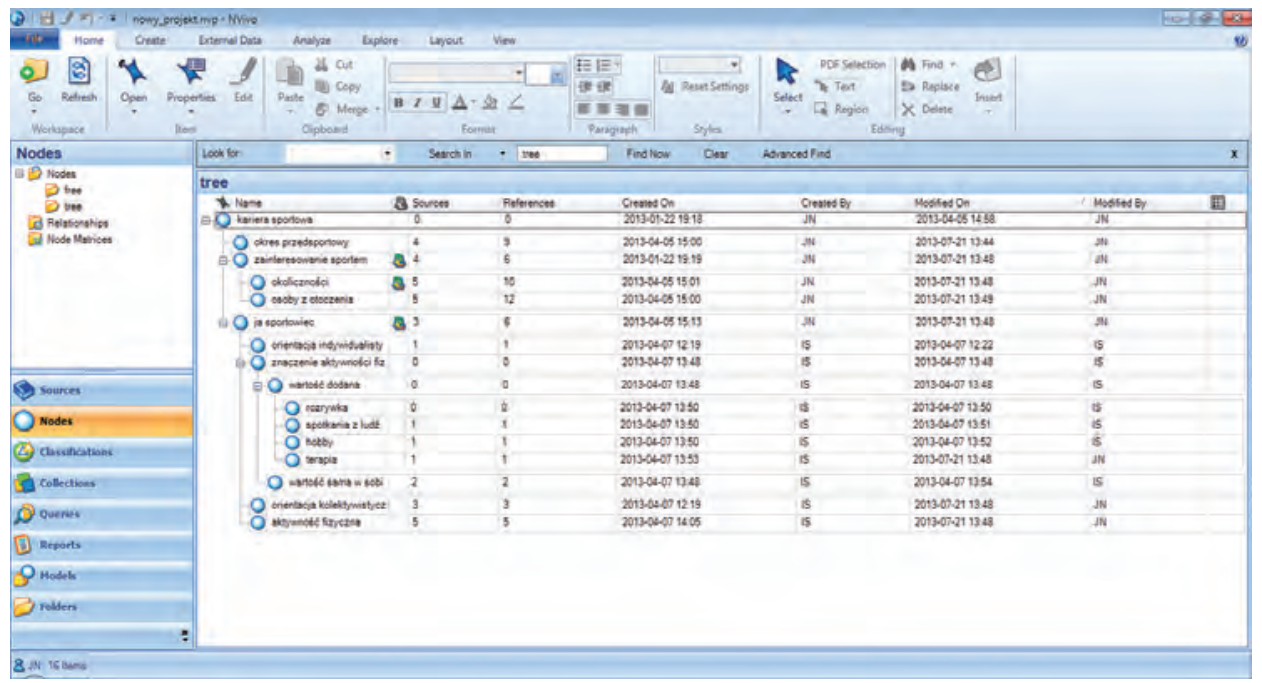

Ilustr. 3. Budowa drzewa kategorii

Źródło: opracowanie własne

Struktura drzewa jest także niezwykle pomocna w utworzeniu kategorii centralnej, która wyłania się w trakcie kodowania zogniskowanego. Kategoria centralna (core category) jest zazwyczaj podstawowym procesem (basic process), a jej istotą jest fakt, że to z nią powiązane są pozostałe kategorie i wokół niej buduje się teoria (Glaser 1998).

Na bazie kodowania zogniskowanego można prowadzić kodowanie selektywne, w którym zebrany materiał analizujemy pod kątem jedynie tych zmiennych i kodów, które związane są z kategorią centralną (core category). W trakcie badań w wypowiedziach rozmówców pojawiają się także liczne kody in vivo, które są wyrazem konceptualnej pracy badanych, ich sposobu myślenia o kluczowych dla nich problemach; są one włączane do budowanej teorii bezpośrednio z języka potocznego i rzeczowego obszaru badań (Strauss, Corbin 1990: 69; Glaser 1998: 137; Miles, Huberman 2000: 64; Konecki 2000: 38; Ślęzak 2009: 44). 
Poza odwzorowaniem struktury kodów w formie drzewa kategorii w programie NVivo można posłużyć się opcją tworzenia relacji pomiędzy kategoriami (Relationship). Używając tej funkcji, można wskazać rodzaj relacji oraz to, czy jest ona jedno- czy dwukierunkowa lub po prostu ustalić sam fakt istnienia zależności bez wskazywania jej kierunku. Dzięki temu uzyskuje się narzędzie wspomagające proces tworzenia hipotez, a więc umożliwiające przechodzenie na wyższy poziom analizy konceptualnej zgodnie z zasadami metodologii teorii ugruntowanej. Przy czym hipoteza w metodologii teorii ugruntowanej nie jest rozumiana jako twierdzenie, które chcemy zweryfikować w wyniku prowadzonego badania (por. Nowak 1985: 35); ma ona raczej charakter tezy ukazującej ugruntowane empirycznie relacje między pojęciami, dla której ustalono warunki występowania (Glaser, Strauss 1967: 36-43; Strauss, Corbin: 1990: 107-108; Konecki 2000: 29; por. Glaser 1998). Bardzo często podczas prowadzenia badań terenowych tego typu relacje między zmiennymi odkrywane są in vivo (Glaser, Strauss 1967: 40). Warto także zaznaczyć, że kategorie mogą być także zapożyczane z już istniejących teorii. Wymaga to jednak dużej ostrożności ze strony badacza i wzięcia pod uwagę odmiennych znaczeń, jakie mogą one ze sobą nieść (Clarke 1991: 146). Ostatecznym kryterium decydującym o ich stosowaniu jest wymóg, by wyłaniały się bezpośrednio z zebranych danych (Glaser, Strauss 1967: 36-37; Strauss, Corbin 1990: 50, 68; Gorzko 2008; por. Ślęzak 2009: 43).

Proces, o którym mowa, nazywa się kodowaniem teoretycznym, które mówi nam o wzajemnych powiązaniach między kategoriami (Glaser 1998: 163). Kodowanie teoretyczne odbywa się poprzez sporządzanie not teoretycznych (theoretical memos), czyli zapisanych w języku teoretycznym myśli badacza o zakodowanych kategoriach i hipotezach (Konecki 2000: 55-57). Noty są zapisem przemyśleń analitycznych związanych z kodami i służą uściśleniu stosowanych kategorii oraz ukierunkowywaniu procesu kodowania. Ponadto, jak podaje Graham Gibbs (2011: 68), są również swoistym łącznikiem między dwoma etapami analizy - kodowaniem i pisaniem raportu. Zdaniem Marka Gorzko (2008: 101) pisemne noty są natomiast swego rodzaju narzędziem analizy, tworząc myślową i teoretyczną przestrzeń, w której badacz dokonuje konceptualizacji danych.

Pisanie not towarzyszy analitykowi stosującemu metodologię teorii ugruntowanej od początku procesu badawczego (Konecki 2000). Noty te mogą dotyczyć całego projektu, zebranych danych w ogóle lub każdego źródła danych z osobna, a także kolejnych etapów analizy oraz poszczególnych kodów (Saillard 2011). Sporządzanie notatek ma zatem kluczowe znaczenie na każdym poziomie procesu kodowania i analizy danych (por. Strauss, Corbin 1990; Niedbalski 2014). 


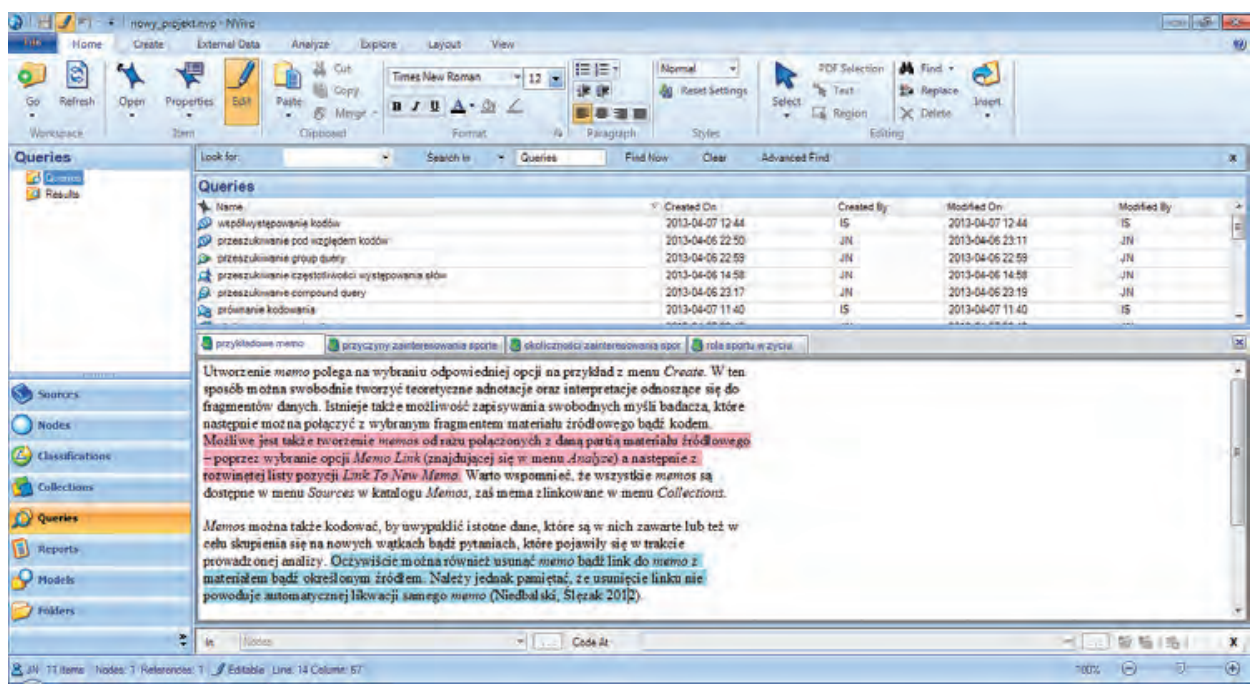

Ilustr. 4. Nota teoretyczna (memo)

Źródło: opracowanie własne

Badacz, zbierając, kodując i analizując materiały, równocześnie na bieżąco decyduje, gdzie i jakiego rodzaju dane zbierać dalej, w czym kluczową rolę odgrywa procedura teoretycznego pobierania próbek (theoretical sampling). Dzięki temu możliwy jest odpowiedni dobór przypadków do porównań. Są one dobierane na podstawie podobieństwa konceptualnego, co umożliwia nasycenie kategorii ich własnościami (tak, by opracować możliwie pełną ich listę) i budowanie nowych hipotez o wyższym poziomie uogólnienia. W związku z tym badacz dąży do zebrania przypadków zarówno bardzo do siebie podobnych (strategia minimalnego porównywania), jak i zdecydowanie różnych (strategia maksymalnego porównywania), tak, by zaobserwować możliwie różnorodne warunki występowania kategorii i ich wzajemnych powiązań (Glaser, Strauss 1967: 45-77; Konecki 2000: 30, 71; por. Charmaz 1994; Urbaniak-Zając, Piekarski 2001: 121). Warto zaznaczyć, że choć dobór próbek do porównań ma charakter otwarty i procesualny, nie jest on chaotyczny, lecz kontrolowany (controlled) poprzez wyłaniającą się teorię. Systematyczność i metodyczność zapewniają procedury metodologii teorii ugruntowanej, takie jak wymóg pisania not teoretycznych i metodologicznych uzasadniających wybory badacza, które pomagają także zidentyfikować moment teoretycznego nasycenia (theoretical saturation; Glaser, Strauss 1967: 45; Glaser 1998; Konecki 2000: 72-73). Oznacza to, że w toku zbierania materiałów nie pojawiają się żadne nowe dane, a pojawiające się przykłady są podobne do już zgromadzonych i można je zanalizować za pomocą istniejących kategorii. Nasycenie osiąga się więc poprzez 
uzupełnianie własności kategorii różnorodnymi danymi (Glaser, Strauss 1967: 61; Strauss, Corbin 1990; Glaser 1998; Konecki 2000: 31-32), które mogą pochodzić z obserwacji, wywiadów, dokumentów zastanych, a mogą to być także dane statystyczne (Glaser, Strauss 1967; Strauss, Corbin 1990: 18; Glaser 1998; Konecki 2000: 31). W takich przypadkach możemy mówić o stosowaniu procedury triangulacji, szczególnie triangulacji danych (por. Konecki 2000; Ślęzak 2009: 42).

W programie NVivo przypadki tworzone są za pomocą funkcji Cases. Na jej podstawie można dodać i określić atrybuty oraz ich właściwości. Przypadki mogą służyć jako reprezentacja poszczególnych osób bądź organizacji stanowiących przedmiot zainteresowań badawczych. Dodatkowo, wykorzystanie opcji Attributes pozwala na przypisanie własności danych metryczkowych określonym przypadkom.

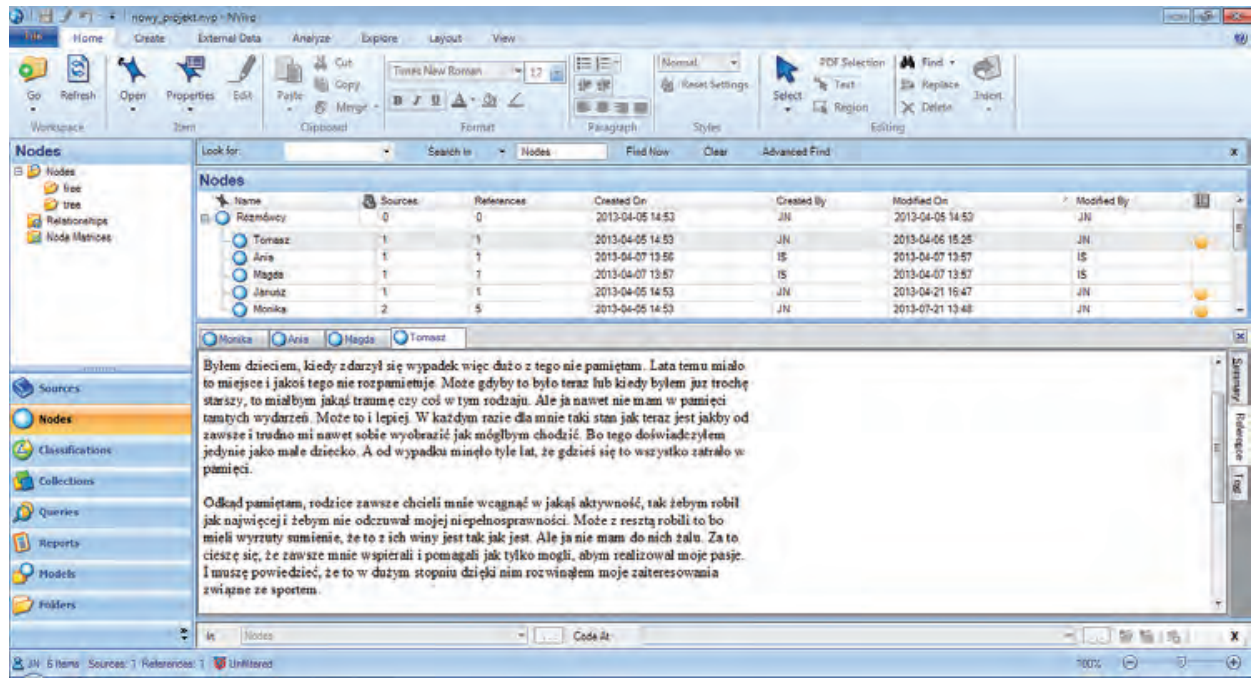

Ilustr. 5. Funkcja tworzenia przypadków (Cases)

Źródło: opracowanie własne

Logika procesu badawczego w metodologii teorii ugruntowanej opiera się na dążeniu do coraz wyższego poziomu konceptualnego, a co za tym idzie - oderwania się od danych ku teoretyzowaniu. $W$ tym kontekście istotne znaczenie ma metoda ciągłego porównywania (constant comparative method), która polega na poszukiwaniu różnic oraz podobieństw pomiędzy fragmentami danych, kodami czy przypadkami (Glaser, Strauss 1967; Strauss, Corbin 1990; Charmaz 1994; Glaser 1998; Konecki 2000: 30-31). Innymi słowy, metoda ciągłego porównywania to konfrontowanie ze sobą różnych składników projektu w celu sprawdzenia 
istniejących między nimi podobieństw bądź wydobyciu pewnych wyróżniających je cech. Na bazie analizy podobieństw i różnic generowane są coraz ogólniejsze kategorie wydobywające na jaw tkwiące u podłoża zjawisk wymiary jednorodności (underlying uniformities) (Gorzko 2008: 86).

Metoda permanentnego porównywania (constant comparative method) opiera się na trzech współzależnych i współwystępujących rodzajach porównań.

Po pierwsze, dotyczy porównywania poszczególnych przypadków w celu ustalenia zarówno ich cech wspólnych, jak i zdecydowane je różnicujących, a także wyszczególnienia warunków, w jakich cechy te występują. Na tej podstawie można wygenerować pojęcia.

Po drugie, pojęcia porównuje się następnie z kolejnymi zaobserwowanymi przypadkami, dzięki czemu można wygenerować nowe teoretyczne własności pojęć i nowe hipotezy, wysycając tym samym własności danego pojęcia-kategorii.

Po trzecie, w tym samym czasie, kiedy dokonywane są ciągle jeszcze porównania pierwszego i drugiego typu, badacz rozpoczyna porównywanie ze sobą pojęć, co ułatwia integrowanie ich w hipotezy (Glaser, Strauss 1967: 101-115; Konecki 2000: 31, 69-75; por. Glaser 1998). Procedura ta pozwala także uniknąć skrzywienia badawczego (Glaser 1998: 142).

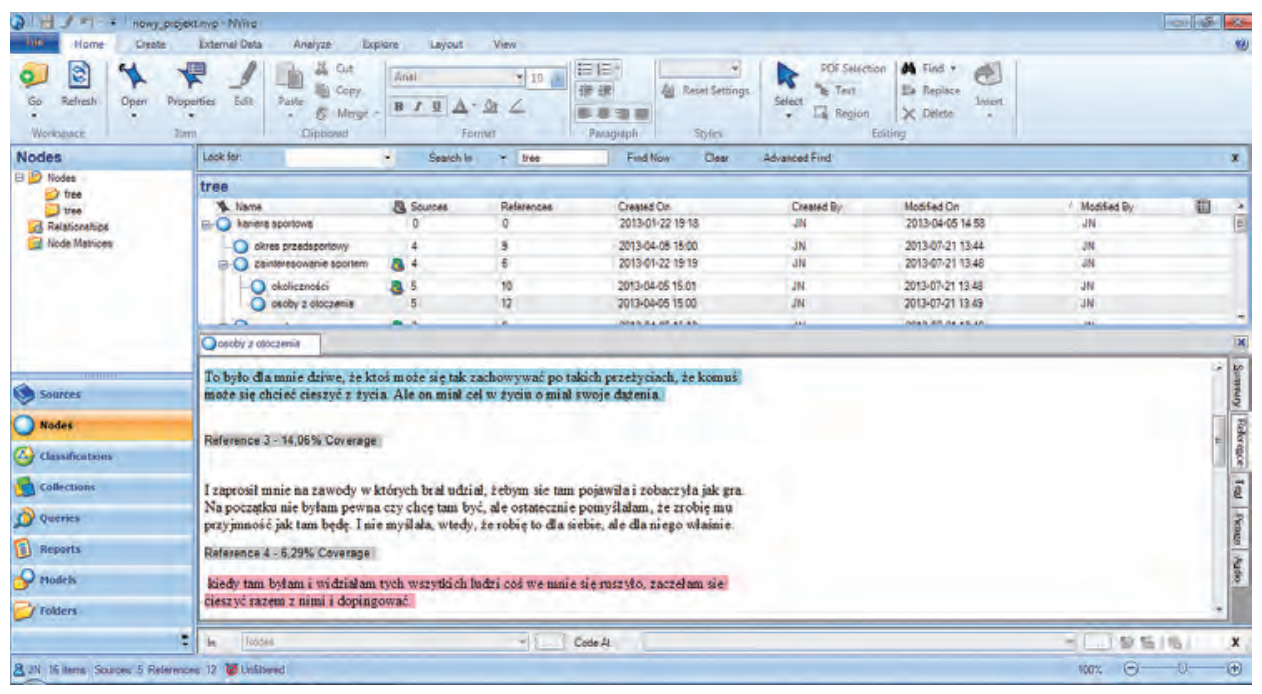

Ilustr. 6. Wyświetlanie zawartości kategorii

Źródło: opracowanie własne

W praktyce podczas korzystania z oprogramowania CAQDA procedurę porównania wykonuje się, stosując opcje wyszukiwania danych. Proces ten polega na przeglądaniu fragmentów tekstu oraz innych rodzajów danych, które zostały 
zakodowane danym kodem. W ten sposób uzyskujemy wiedzę na przykład odnośnie tego, jak na dany temat, który został przez badacza ujęty w formie kategorii analitycznej, wypowiadają się poszczególni rozmówcy.

W przeprowadzaniu porównań danych dobrze sprawdzają się tabele porównawcze. Umożliwiają przedstawienie fragmentów tekstu wybranych z całego zbioru danych w formie ułatwiającej systematyczne porównywanie (Gibbs 2011: 141). Ich efektem mogą stać się wygenerowane typologie - dzielące zbiór wszystkich analizowanych przypadków na podzbiory w taki sposób, że każdy z nich zostaje przypisany tylko do jednego z wyodrębnionych typów (Gibbs 2011: 150-154).

Dzięki wykorzystaniu tego narzędzia możliwe staje się skondensowanie objętościowo dużych materiałów i ich tematyczne posegregowanie na bardziej przystępne i czytelne fragmenty, które w znacznie prostszy sposób można ze sobą porównywać.

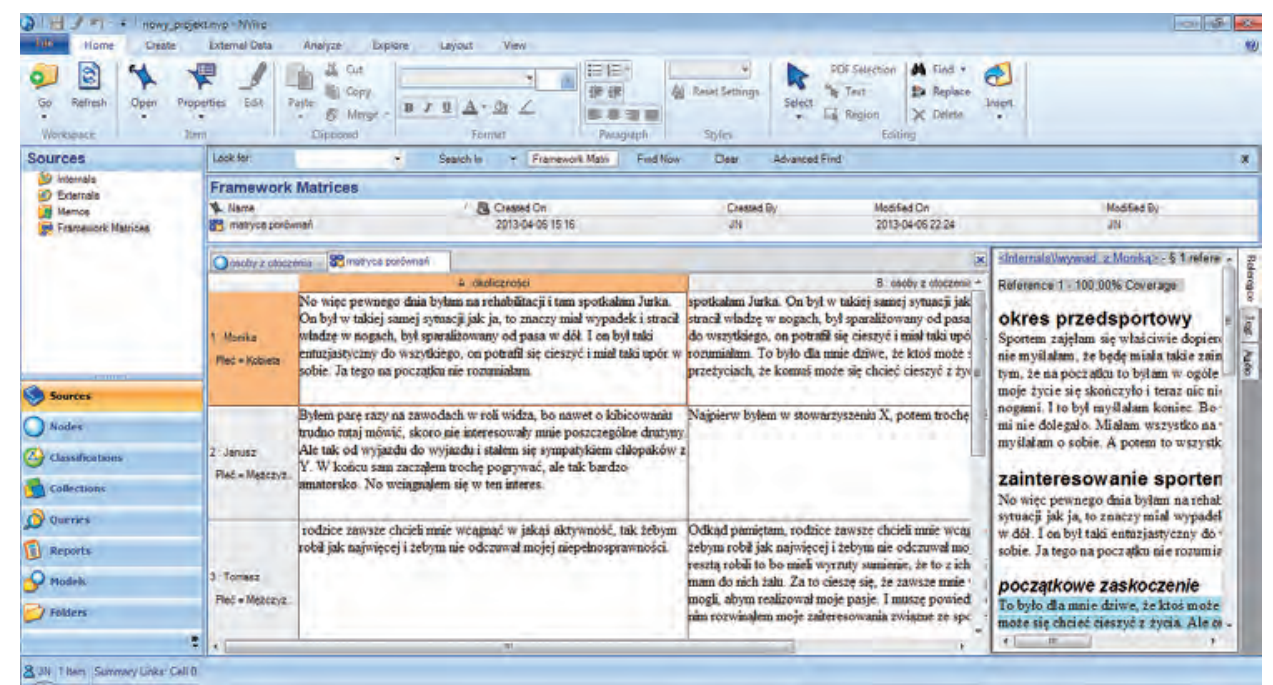

Ilustr. 7. Matryca kategorii

Źródło: opracowanie własne

W generowaniu teorii pomocne jest także tworzenie wizualnych reprezentacji wygenerowanych kategorii obrazujących związki między nimi i pozwalających uzyskać dystans do zebranych danych (por. Strauss, Corbin 1990: 198-222; Glaser 1998: 91; Ślęzak 2009: 44). Z perspektywy metodologii teorii ugruntowanej najistotniejsze zdają się modele będące podstawą diagramów integrujących dane. 
W programie NVivo można użyć funkcji tworzenia modeli do określenia oraz przeglądu wstępnych pomysłów oraz idei na temat interesujących badacza pytań, a także wizualnego przedstawienia relacji między elementami projektu, zidentyfikowania pojawiających się wzorów, teorii oraz wyjaśnień czy udokumentowania i zapisu kolejnych etapów pracy nad projektem.

Dzięki wykorzystaniu tej funkcji badacz może w sposób bardziej przejrzysty przedstawić szkic projektu bądź wizję swoich pomysłów związanych z opracowaniem materiału (Miles, Huberman 2000; Seale 2008). Modele mogą bowiem odzwierciedlać aktualne modyfikacje wynikające z procesu analitycznego i pokazywać bieżące pomysły analityka (Niedbalski, Ślęzak 2012: 152).

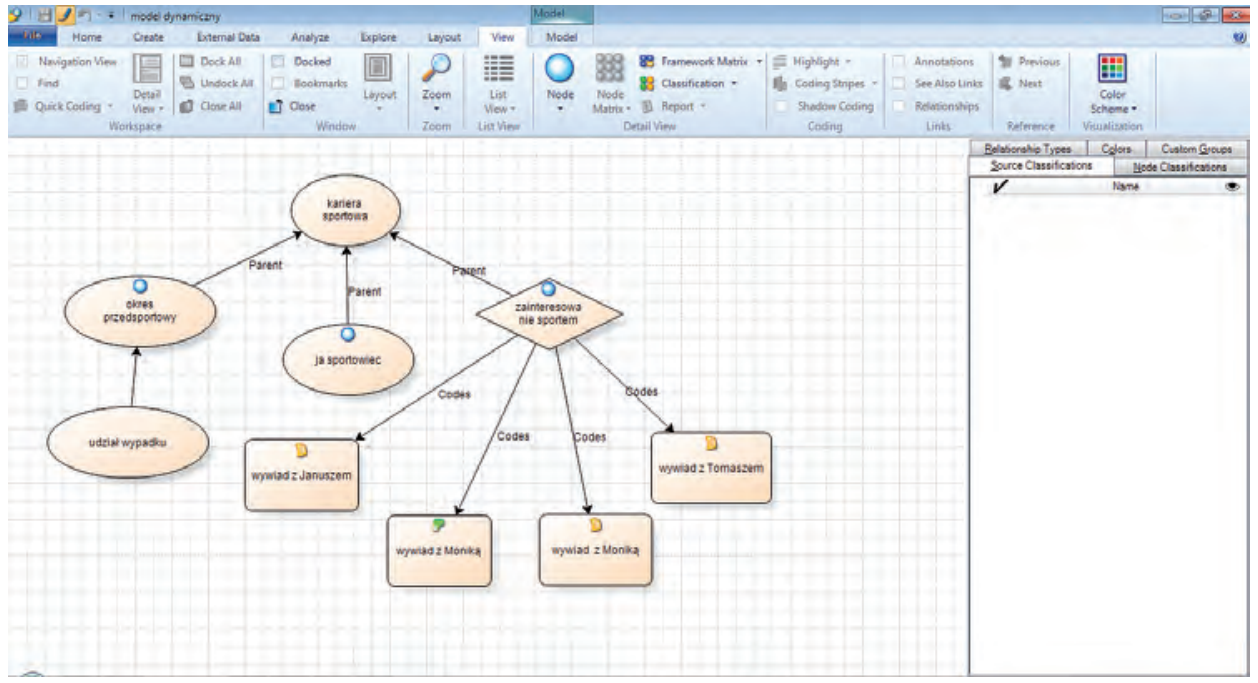

Ilustr. 8. Diagram integrujący

Źródło: opracowanie własne

Program NVivo, poza zaprezentowanymi funkcjami, które wspierają proces generowania teorii, posiada wiele innych ciekawych i przydatnych opcji. Wspomnieć tutaj można chociażby o rozbudowanym narzędziu przeszukiwania danych, stosowanym zarówno do prowadzenia kwerendy obecnych w materiałach tekstowych informacji (słów, fraz), jak i dotyczącej wygenerowanych przez badacza kategorii.

Przydatną funkcją oferowaną w programie NVivo jest możliwość upowszechniania wyników przeprowadzonych za jego pośrednictwem analiz. Badacz może skorzystać $z$ jednej $z$ wielu dostępnych opcji eksportowania danych $w$ formie czytelnej dla popularnych programów biurowych (Niedbalski, Ślęzak 2012: 152). Sposobem upowszechniania danych jest także tworzenie raportów z badań, które 
mogą stanowić ilustrację pewnego etapu analizy bądź końcowego opracowania wyników badań, a także wyeksportowanie utworzonych w programie wykresów i modeli w postaci zdjęć.

Te i wiele innych funkcji, jakie kryje w sobie program NVivo, stanowią ważny potencjał, który odpowiednio wykorzystany przez badacza może stać się niezwykle pomocny w procesie prowadzenia analizy danych i to niezależnie od stosowanej metody badawczej. Niemniej biorąc pod uwagę realizację badań opartych na procedurach metodologii teorii ugruntowanej, wskazane $w$ artykule funkcje i sposoby ich wykorzystania stanowią podstawową bazę narzędzi, zwłaszcza dla początkującego analityka. Z czasem może ona zostać poszerzona o kolejne opcje, które z pewnością w jeszcze większym zakresie wspomogą pracę badacza.

\section{Podsumowanie}

Program NVivo to narzędzie uniwersalne, wyposażone w szereg przydatnych funkcji, które powinny zaspokoić oczekiwania badaczy reprezentujących rozmaite szkoły teoretyczne i metody badacze. Niektóre z nich są szczególnie ważne i przydatne dla badaczy wykorzystujących MTU, inne zaś będą pomocne niezależnie od tego, jakie podejście analityczne zastosowano w projekcie (Niedbalski, Ślęzak 2012: 156).

Z perspektywy metodologii teorii ugruntowanej zaletą oprogramowania NVivo jest z pewnością możliwość zorganizowania jednej bazy danych z różnego rodzaju materiałów źródłowych (Wiltshier 2011). Ważną cechą programu NVivo jest również to, iż pozwala on na porządkowanie różnych elementów projektu, zarówno materiałów źródłowych, jak i wszelkich informacji będących wytworem badacza zaangażowanego $\mathrm{w}$ analizę danych - a więc de facto wytworów analizy. Badacze stosujący MTU z pewnością docenią też możliwość pisania różnego rodzaju notatek i tworzenia drzewa kodów, co sprzyja prowadzeniu systematycznej analizy. Program NVivo umożliwia bowiem płynne przechodzenie między kodowaniem otwartym, zogniskowanym, pisaniem memos i budowaniem modelu (Modeling).

Warto zaznaczyć, że sama architektura programu niejako wymusza nieustanne myślenie o związkach między kodami a kategoriami, ich porównywanie oraz modyfikowanie tworzonego przez badacza układu. Sprzyja także koncentracji na kategorii centralnej, wokół której powinny skupiać się działania analityka (Konecki 2000).

Pomimo wielu zalet przemawiających za zbieżnością wewnętrznej architektury oprogramowania i procedur MTU struktura programu sprawia, że niektórzy badacze mogą zarzucić NVivo zbytnią sztywność i konieczność podporządkowania 
analizy rozwiązaniom zaimplementowanym przez konstruktorów oprogramowania. Posługiwanie się oprogramowaniem komputerowym wymaga nie tylko metodologicznej i teoretycznej sprawności, lecz także zapoznania się ze specyfiką konkretnego programu i jego funkcjami (Niedbalski, Ślęzak 2012: 160). Czasami podkreśla się także, że konstruktorzy programu, starając się nadać mu uniwersalny charakter, stworzyli narzędzie, które jest na tyle rozbudowane, że przestało w ogóle spełniać wymagania jakiejkolwiek metody badawczej. Wydaje się jednak, że w przypadku oprogramowania NVivo jest to raczej kwestia sposobu wykorzystania możliwości programu przez danego użytkownika, nie zaś samej architektury oprogramowania (Niedbalski, Ślęzak 2012: 159). Przede wszystkim zaś należy pamiętać, że oprogramowanie komputerowe jest tylko narzędziem, zaś od badacza zależy sposób jego wykorzystania. Ostatecznie to on sam i jego umiejętności analityczne, a także związane z obsługą konkretnego programu będą kluczowe w kontekście jakości realizowanych badań i otrzymanych na ich podstawie wyników.

\section{Bibliografia}

Bokszański Zbigniew (1986), Koncepcja tożsamości jednostki w pracach A. L. Straussa, „Studia Socjologiczne", nr 2, s. 89-110.

Charmaz Kathy (1994), Grounded Theory. Objectivist and Constructivist Methods, [w:] Norman Denzin, Yvonne Lincoln (eds), Handbook of Qualitative Research, Sage Publications, London. Clarke Adele (1991), Social Worlds/Arenas Theory as Organizational Theory, [w:] David R. Maines (ed.), Social Organization and Social Processes: Essays in Honor of Anselm Strauss, Aldine De Gruyter, New York.

Gibbs Graham (2011), Analizowanie danych jakościowych, przeł. Maja Brzozowska-Brywczyńska, Wydawnictwo Naukowe PWN, Warszawa.

Glaser Barney (1998), Doing Grounded Theory: Issues and Discussions, Sociology Press, Mill Valley. Glaser Barney G. (1978), Theoretical Sensitivity, The Sociology Press, San Francisco.

Glaser Barney, Strauss Anselm (1967), The Discovery of Grounded Theory. Strategies for Qualitative Research, Aldine Publishing Company, New York.

Gorzko Marek (2008), Procedury i emergencja. O metodologii klasycznych odmian teorii ugruntowanej, Wydawnictwo Naukowe Uniwersytetu Szczecińskiego, Szczecin.

Hammersley Martyn, Atkinson Paul (2000), Metody badań terenowych, Wydawnictwo Zysk i S-ka, Poznań.

Konecki Krzysztof (2000), Studia z metodologii badań jakościowych. Teoria ugruntowana, Wydawnictwo Naukowe PWN, Warszawa.

Merton Robert (2002), Teoria socjologiczna i struktura społeczna, PWN, Warszawa.

Miles Matthew, Huberman Michael A. (2000), Analiza danych jakościowych, Trans Humana, Białystok.

Niedbalski Jakub (2014), Komputerowe wspomaganie analizy danych jakościowych. Zastosowanie oprogramowania NVivo i Atlas.ti w projektach badawczych opartych na metodologii teorii ugruntowanej, Wydawnictwo Uniwersytetu Łódzkiego, Łódź. 
Niedbalski Jakub, Ślęzak Izabela (2012), Analiza danych jakościowych przy użyciu programu NVivo a zastosowanie procedur metodologii teorii ugruntowanej, „Przegląd Socjologii Jakościowej", t. 8, nr 1, s. 126-165; www.przegladsocjologiijakosciowej.org [dostęp: 20.11.2013].

Nowak Stefan (1985), Metodologia badań społecznych, Wydawnictwo PWN, Warszawa.

Piotrowski Andrzej (1985), Osobowość a tożsamość. O pewnej tendencji w socjologii interakcji, Folia Sociologica, nr 12, s. 19-45.

Saillard Elif K. (2011), Systematic Versus Interpretive Analysis with Two CAQDAS Packages: NVivo and MAXQDA, „Forum: Qualitative Social Research”, vol. 12, no. 1; www.qualitative-research.net/index.php/ fqs/article/view/1518 [dostęp: 30.11.2013].

Schönfelder Walter (2011), CAQDAS and Qualitative Syllogism Logic-NVivo 8 and MAXQDA 10 Compared, „Forum: Qualitative Social Research”, vol. 12, no. 1; www.qualitative-research. net/index.php/fqs/article/view/1514 [dostęp: 30.11.2013].

Strauss Anselm, Corbin Juliet (1990), Basics of Qualitative Research. Grounded Theory Procedures and Techniques, Sage Publications Newbury Park, London, New Delhi.

Ślęzak Izabela (2009), Stawanie się poetq̨. Analiza interakcjonistyczno-symboliczna, „Przegląd Socjologii Jakościowej", t. V, nr 1, s. 1-175.

Urbaniak-Zając Danuta, Piekarski Jacek (2001), Jakościowe orientacje w badaniach pedagogicznych. Studia i materiały, Wydawnictwo Uniwersytetu Łódzkiego, Łódź.

Wiltshier Fiona (2011), Researching with NVivo, „Forum: Qualitative Social Research”, vol. 12, no. 1; www.qualitative-research.net/index.php/fqs/issue/view/36 [dostęp: 12.09.2011].

Ziółkowski Marek (1981), Znaczenie, interakcja, rozumienie, Wydawnictwo Naukowe PWN, Warszawa.

\section{The Main Features of NVivo Software and the Procedures of Methodology of Grounded Theory. How to Implement Study Based on the MTU Using the CAQDA?}

Summary. The aim of the article is to introduce the reader to the possibilities offered by the software supporting the analysis of qualitative data in research projects based on qualitative methods. The analysis is NVivo software and its functions. In this article we present the way in which the options of this program should be used to constitute an effective means to conduct research in accordance with the procedures of methodology of grounded theory.

Keywords: Computer-Assisted Qualitative Data Analysis Software (CAQDAS), NVivo software, methodology of grounded theory (MTU). 